\title{
Impact of Demonstration of Fodder Plot at Farmer's Field
}

\author{
V. Jayalalitha*, P. N. Richard Jagatheesan and K. Shibi Thomas \\ Veterinary University Training and Research Centre, \\ 7/2, Kozhipannai Road, Kottapattu, Tiruchirappalli 620 023, India \\ *Corresponding author
}

\section{A B S T R A C T}

\section{Keywords \\ Fodder plot demonstration, Economy, Cost of milk production \\ Article Info \\ Accepted: \\ 28 July 2020 \\ Available Online: \\ 10 August 2020}

This study is aimed to popularize the fodder cultivation and its importance in livestock rearing. Four number of fodder plot demonstration units were established at Thuraiyur, Tiruchirappalli district. Farmers skill and income were improved due to this demonstration. There were a good number of farmers engaged in livestock rearing motivated to fodder cultivation by this extension approach. The cost of production of milk was reduced to Rs.6-7 per litre.

\section{Introduction}

In India, livestock sector is a major enterprise having many problems in improving production and productivity. Livestock rearing with fodder cultivation is the best option to mitigate the issues in cost of production and productivity.

In recent years, government and nongovernmental organizations were attempted to improve and popularize the fodder cultivation among the farmers. But there were miles to go to achieve fodder cultivation due to lack of awareness, inputs, pressure to cultivate commercial crops, economy of the farmer etc. Thuraiyur is the backward block in Tiruchirappalli district due to its draught conditions and lack of industries.

Livestock rearing is the common practice of people for their livelihood. This study focused to the dairy farmers for improving their livestock business with fodder cultivation.

With these points, this study is aimed to popularize the fodder cultivation to improve the livestock farmer's economy by reducing the cost of production. 


\section{Materials and Methods}

NABARD funded scheme on "Popularization of fodder cultivation to improve the livestock production to rural folks in Tiruchirappalli district" was being operated at Veterinary University Training and Research Centre, Tiruchirappalli during 2015-16. In that scheme, four villages were identified from Thuraiyur block of Tiruchirappalli district and in each village 25 farmers were attended the training programme.

All the hundred farmers were taken to field visit for fodder plots, Krish Vigyan Kendra and private farms. Improved and novel varieties of fodder were discussed in these training. Pre and post exposure training, the knowledge level of the farmers was recorded by questionnaire about the fodder cultivation and its importance. In each village training programme, successful farmer was identified and demonstration fodder plot was established at the farmer's field. Totally four demonstrations plots were made with grass (Co4), legumionous (Hedge Leucern), cereal (CoFS 29) and tree fodder (Agathi). Land modification, procuring root slips, sowing of fodder seeds or root slips, fertilizer/manure application, harvesting of fodder etc. were demonstrated.

The idea of demonstrations made at farmer's field was to attract other farmers to practice fodder cultivation. Each fodder plot is having 20 cents of land and the inputs viz., fodder seeds/ slips and irrigation cost etc., were provided to the farmer. Stepwise procedure to cultivate all type of fodder was demonstrated. Challenges in cultivation processes faced by the farmers were rectified by the technical people in the field. Timely advisory services by the technical staff helped the beneficiaries to a great extent. Watering done at once in a week and periodical monitoring was done by the investigators in all the four fields.
Harvesting of forage grass, leguminous and cereal fodder was done after 60-70 days of planting. The data in the farmer's field were recorded viz., yield of fodder, quantity of fodder fed to their livestock and cost of production after fodder feeding. After the project period, all the four demonstration plots were monitored and survey was conducted in the villages about fodder cultivation.

\section{Results and Discussion}

\section{Improved knowledge level of farmers on fodder}

According to baseline survey conducted in four villages of Thuraiyur, $90 \%$ of the farmers reared their livestock without fodder cultivation (Table 1). The others cultivated only grass varieties Co4 and Co5. Almost all the farmers were unaware of different fodder varieties. Pre and post exposure training questionnaire reveled that, farmer's skills and knowledge on awareness about fodder varieties, fodder cultivation methods, importance of fodder in livestock rearing etc. were improved. Field visit gave more attention to the farmers towards fodder cultivation.

\section{Improved fodder production}

With 20 cents of irrigated land, a farmer reared two cows without troubling in feeding. 60-70 kg of all varieties of fodder was cut for two animals daily. Cereal, leguminous, grass fodders and tree fodders could be harvested in 20 cents of land to meet out the nutritional requirements of two cows. Since all the demonstrated varieties are multicut fodder, it was available round the year. Before this study there was only 10 percent of the livestock farmers cultivated the grass fodder (Table 1). This finding is coordinated with the report of Swain et al., 2015 who surveyed 
three districts of Odhisa for fodder availability among the livestock farmers and reported that only 14 percent of the farmers cultivated only grass and not any other fodder.

\section{Improved milk production and economy of the farmer}

After the training programmes, these farmers follow scientific feeding practices which include dry fodder, green fodder, concentrate feeding, chaff cutting, conservation of surplus fodder etc. As expected, consumption of green fodder has improved the overall health status and productivity of the dairy animals.

With respect to milk production cost, dairy farmers faced an economic crisis in feed cost. For a litre of milk produced, a farmer had to spent Rs. 30-35/- which is very serious issue in sustainability of dairy farming. Feeding of green fodder reduced the cost of production of milk which was upto Rs.6-7 per litre. On an average, farmers get reduced the cost of production Rs.30/cow/day by feeding mixed fodder varieties. (Table 2)

As green fodder are the comparatively cheaper source of essential nutrients, their inclusion in diet significantly reduced cost of feeding in terms of rupees per day, subsequently reduced the cost of milk production and generates higher net daily income. Hossain et al., (2017) reported that average daily feeding cost reduced significantly by $12.70 \% \quad(\mathrm{P}<0.05) \quad$ in experimental group as compared to control group. Net daily income of farmers increased significantly by Rs. $31.03 \quad(\mathrm{P}<0.05)$ after incorporating green fodder in the ration of buffaloes. The cost of milk production also reduced from Rs. 17.65 to 15.31 per $\mathrm{kg}$. Khan et al., (2009) found that income of farmers was two folds higher when green fodder was fed to the animals during monsoon and winter season. Similarly, Sanh et al., (2002) also stated that the feed cost per kg milk produced was lowest for the cows fed $70 \%$ forage, followed by the cows fed $50 \%$ forage and then the cows fed $30 \%$ forage

\section{Popularized fodder cultivation}

After project period (2015-16), all the four demonstration plots were extended by themselves during 2017-18 and they increased their number of animals. They are supplying fodder and fodder slips to the dependent farmers. By "seeing is believing" concept fodder cultivation is being adopted by livestock farmers in those villages. Recently twenty new farmers from all the four villages are practicing fodder cultivation and almost 70 percent farmers adopted the forage feeding to their livestock (Table 3). Vinothraj et al., (2019) reported that 16 seed units had developed with 5 demonstration units of mixed fodder varieties at Erode district, Tamilnadu.

Table.1 Improvement of farmer's skill before and after the training and field visit exposure (\%)

\begin{tabular}{|l|c|c|}
\hline Farmers skill & Pre exposure (\%) & Post exposure (\%) \\
\hline Fodder cultivation & 10 & 98 \\
\hline Fodder varieties & 0 & 99 \\
\hline $\begin{array}{l}\text { Forage feeding to } \\
\text { their livestock }\end{array}$ & 22 & 87 \\
\hline Scientific feeding & 1 & 95 \\
\hline $\begin{array}{l}\text { Scientific practices } \\
\text { in livestock farming }\end{array}$ & 6 & 97 \\
\hline
\end{tabular}


Table. 2 Cost of production of milk in comparison with fodder feeding

\begin{tabular}{|l|l|l|l|}
\hline Cost of feed for 4 litre of milk & Unit cost & With fodder & Without fodder \\
\hline Oil cake-1 kg & $35 / \mathrm{kg}$ & 17.5 & 35 \\
\hline $\begin{array}{l}\text { Cereals maize, sorghum etc - 2 } \\
\text { kg }\end{array}$ & $23 / \mathrm{kg}$ & 23 & 46 \\
\hline Rice bran -3 kg & $15 / \mathrm{kg}$ & 15 & 45 \\
\hline Fodder-10 kg & $20 / 5 \mathrm{~kg}$ & 40 & - \\
\hline Total cost & & $\mathbf{9 5 . 5}$ & $\mathbf{1 2 6}$ \\
\hline $\begin{array}{l}\text { Total cost of production per } \\
\text { litre of milk }\end{array}$ & $\begin{array}{l}95.5 / 4 \\
=23.8\end{array}$ & $\begin{array}{l}126 / 4 \\
=31.5\end{array}$ \\
\hline
\end{tabular}

Table.3 Adaptation of fodder cultivation and livestock rearing with fodder feeding

\begin{tabular}{|l|c|c|}
\hline Year & Fodder plot (No. of farmers) & Fodder feeding $(\boldsymbol{\%})$ \\
\hline $\mathbf{2 0 1 5}-16$ & 4 (demonstration fodder plot) & 10 \\
\hline $\mathbf{2 0 1 6 - 1 7}$ & 10 & 30 \\
\hline $\mathbf{2 0 1 7 - 1 8}$ & 16 & 40 \\
\hline $\mathbf{2 0 1 8 - 1 9}$ & 20 & 70 \\
\hline
\end{tabular}

There was a promotional change in the attitude of beneficiaries about fodder cultivation and feeding fodder to their livestock. Before this study, the farmers considered this practice is difficult to adopt at their field due to non-availability of inputs and lack of scientific knowledge. At present, good number of farmers in the selected villages adopted the fodder cultivation due to awareness programmes, field visit and method demonstration. With the introduction of the project, beneficiaries have initiated fodder production due to realisation of minimal cost of production in livestock rearing and easy to cultivate the fodder.

Fodder cultivation is one of the best practice to rear the dairy with less cost. To increase the dairy farming activities among the farmers, availability of quality feed and fodder are essential. The existing government schemes on subsidies to farmers for cultivation of fodder and chaff cutter may be extended to motivate the fodder cultivation.

\section{References}

Hossain SA, Sherasia PL, Phondba, BT Pathan FK and Garg MR. 2017. Effect of feeding green fodder based diet in lactating buffaloes: Milk production, economics and methane emission. Indian J Dairy Sci 70(6):767-773 .

Khan MJ, Peters KJ, Uddin MM (2009) Feeding strategy for improving dairy cattle productivity in small holder farm in Bangladesh. Bangladesh J Anim Sci 38(1-2): 67-85.

Sanh MV, Wiktorsson H, Ly LV (2002) Effects of natural grass forage to concentrate ratios and feeding principles on milk production and performance of 
crossbred lactating cows. Asian-Aust J Anim Sci15(5): 650-657S

Swain BB , Singh DK, Sahoob P K, Teufelb N , Pandac N and Laparb N. 2015. Feed and Fodder Availability at Farmers' Level: The Study of Puri, -Bhadrak and Mayurbhanj District of Odishaa. souevenir of International workshop on improving the livestock feeding practices and enhancement of feed and fodder availability in Odhisha. Vinothraj, S., P. Alagesan, S. Saravanakumar and Srinivasan, R.D. 2019. Impact of Mixed Fodder Cultivation in Dairy Cattle Milk Yield. Int.J.Curr.Microbiol.App.Sci. $\quad 8(03)$ : 1000-1003. doi: https://doi.org/10.20546/ijcmas.2019.80 3.121

\section{How to cite this article:}

Jayalalitha, V., P. N. Richard Jagatheesan and Shibi Thomas, K. 2020. Impact of Demonstration of Fodder Plot at Farmer's Field. Int.J.Curr.Microbiol.App.Sci. 9(08): 39153919. doi: https://doi.org/10.20546/ijcmas.2020.908.450 